https://doi.org/10.15407/ukrbotj76.05.427

\title{
Distribution and preliminary assessment of a rare fungus Hemileccinum depilatum (Boletales, Basidiomycota) in Ukraine
}

\author{
Vasyl P. HELUTA ${ }^{1}$, Boris ASSYOV ${ }^{2}$, Vera P. HAYOVA ${ }^{1}$ \\ ${ }^{1}$ M.G. Kholodny Institute of Botany, National Academy of Sciences of Ukraine \\ 2 Tereschenkivska Str., Kyiv 01004, Ukraine \\ vheluta@botany.kiev.ua \\ ${ }^{2}$ Institute of Biodiversity and Ecosystem Research, Bulgarian Academy of Sciences \\ 2 Yurii Gagarin Str., Sofia 1113, Bulgaria \\ contact@boletales.com
}

Heluta V.P., Assyov B., Hayova V.P. 2019. Distribution and preliminary assessment of a rare fungus Hemileccinum depilatum (Boletales, Basidiomycota) in Ukraine. Ukrainian Botanical Journal, 76(5): 427-433.

Abstract. Hemileccinum depilatum (Boletales, Basidiomycota) is currently known from Western and Central Europe, the Mediterranean, the Balkan Peninsula, and Asia (Azerbaijan and Turkey). The fungus is rare throughout its range and is included in the Red Lists in several European countries. In Ukraine, the species is known since 2006. Formerly, H. depilatum was found on the South Coast of Crimea, in the Mountain Crimea, Western Forest-Steppe and the Carpathians. The species was recorded only in five localities in three regions of Ukraine: Khmelnytsky, Transcarpathian, and the Autonomous Republic of Crimea. Over the recent years, the fungus has been also reported from the following five regions: Cherkasy, Ivano-Frankivsk, Kyiv, Lviv, and Ternopil. Thus, by now the total number of the species localities increased from 5 to 14 . However, the number of records grows due to additional data recently provided from field observations by amateur mycologists, rather than it can be considered as a result of an increasing population trend of the fungus. Undoubtedly, $H$. depilatum is a rarely occurring species in Ukraine and is to be protected. A preliminary assessment of the species at the national level using the IUCN criteria and categories is provided. Today, the main threat to its existence is collection of the fruit bodies by local population. Therefore, it is proposed to continue searching for new localities of the fungus and to protect those sites at least at the regional level, as well as to provide public outreach, primarily through social networks, which nowadays bring together tens of thousands of amateur mycologists in Ukraine.

Keywords: Boletaceae, Boletus, fungal conservation, IUCN, Hemileccinum impolitum, Leccinum, rare fungus, Xerocomus

Submitted 03 October 2019. Published 31 October 2019

Гелюта В.П. ${ }^{1}$, Асьов Б. ${ }^{2}$, Гайова В.П. ${ }^{1}$ 2019. Поширення в Україні та попередня оцінка рідкісного гриба Нетіleccinum depilatum (Boletales, Basidiomycota). Український ботанічний журнал, 76(5): 427-433.

${ }^{1}$ Інститут ботаніки ім. М.Г. Холодного НАН України

вул. Терещенківська 2, Київ 01004, Україна

${ }^{2}$ Інститут біорізноманіття та екосистемних досліджень, Академія наук Болгарії вул. Юрія Гагаріна 2, Софія 1113, Болгарія

Реферат. Hemileccinum depilatum (Boletales, Basidiomycota) трапляється у Західній та Центральній Європі, Середземномор'ї, на Балканському півострові, а також в Азії (Азербайджан і Туреччина). Скрізь він є рідкісним, у ряді країн Європи внесений до природоохоронних списків. В Україні він відомий з 2006 р. Гриб знаходили на Південному березі Криму, у Гірському Криму, Західному Лісостепу та Карпатах. До цього дослідження в Україні було відомо лише п'ять його місцезнаходжень, розташованих в Автономній Республіці Крим, Закарпатській і Хмельницькій областях. Упродовж останніх років гриб був зареєстрований ще у п'яти областях - Івано-Франківській, Київській, Львівській, Тернопільській і Черкаській, а кількість відомих локалітетів виду зросла з 5 до 14. Однак це збільшення пов'язане насамперед з широким залученням до пошуків даного виду мікологів-аматорів, а не є наслідком тенденції до збільшення чисельності гриба. Отже, $H$. depilatum є рідкісним в Україні видом і потребує охорони. Здійснено попередню оцінку виду на національному рівні із застосуванням критеріїв та категорій МСОП. На сьогодні головною загрозою для його існування є збір плодових тіл населенням. Тому пропонується продовжувати пошук нових місцезнаходжень цього рідкісного гриба, брати їх під охорону хоча б на регіональному рівні, а також здійснювати роз'яснювальну роботу з населенням, насамперед через соціальні мережі, які на сьогодні об'єднують в Україні десятки тисяч мікологів-аматорів.

Ключові слова: Boletaceae, Boletus, Hemileccinum impolitum, Leccinum, Хerocomus, МСОП, охорона грибів, рідкісний гриб

(C) 2019 V.P. Heluta, B. Assyov, V.P. Hayova. Published by the M.G. Kholodny Institute of Botany, NAS of Ukraine. This is an open access article under the terms of the Creative Commons Attribution License (http://creativecommons.org/licenses/by/4.0/), which permits use, distribution, and reproduction in any medium, provided the original work is properly cited 
Hemileccinum Š utara is one of the smallest genera of the Boletaceae (Boletales, Basidiomycota) currently comprising five species (http://www.indexfungorum. org/names/Names.asp). The genus was described by J. Sutara (2008) to include two species then placed in Xerocomus Quél., as H. depilatum (Redeuilh) Šutara and H. impolitum (Fr.) Šutara. Formerly they were regarded by different authors as belonging to three genera, Boletus L., Leccinum Gray, and already mentioned Xerocomus. However, the two species were transferred to Hemileccinum, once it was noticed that anatomical structure of the peripheral stipe layers in both species is of the leccinoid type (i.e. corresponding to that of Leccinum) (Bertault, 1980; Šutara, 2008). Therefore these species could be referred neither to Boletus, nor to Xerocomus. This conclusion was supported by molecular phylogenetic analyses; moreover, studies on phylogenetic relationships have demonstrated that both species are also rather distant from Leccinum (Binder, Besl, 2000; Bakker, Noordeloos, 2005). Thus, a new genus was proposed based on distinct morphology and phylogenetic data. Morphologically, the genus appears similar to Leccinum, but its species differ in having the yellow hymenophore, unchanging in color context, iodoform odor, and violet macrochemical reaction of the pileus surface with $\mathrm{NH}_{3}$ vapour (Šutara, 2008). Furthermore, multigenous analysis of highly informative genetic markers showed a distinct phylogenetic lineage and clearly supported Hemileccinum as a separate genus (Wu et al., 2014).

Subsequently, based on molecular phylogenetic evidence and morphological data (Halling et al., 2015; Wu et al., 2016), other two species, the Southeast Asian Boletus indecorus Massee [Corneroboletus indecorus (Massee) N.K. Zeng \& Zhu L. Yang] and the North American B. subglabripes Peck, were transferred to Hemileccinum; in addition, a new species, $H$. rugosum $\mathrm{G}$. Wu \& Zhu L. Yang, was described from southwestern China. Thus of the currently known five species of Hemileccinum, only two are native to Europe, $H$. depilatum and $H$. impolitum. The latter is quite widespread, while $H$. depilatum is a rarely occurring species. It has been reported from Western and Central Europe, the Mediterranean, the Balkans (http://e-ecodb.bas.bg/rdb/bg/vol1/Boldepil.html) and Asia (Azerbaijan and Turkey) (Doğan et al., 2012; Mustafabayli, Aghayeva, 2019). Due to its rarity, the species was included in the Red Lists of fungi in several European countries. In Bulgaria, H. depilatum is redlisted as Endangered (EN B2ab(iii)) (Gyosheva et al.,
2006; Assyov, Denchev, 2015). In the fungal Red List of the Czech Republic it is categorized as Vulnerable (Holec, Beran, 2006; Sutara et al., 2009), in the Red List of Fungi for Great Britain - as Data Deficient (Ainsworth et al., 2013). In Poland, only two records of $H$. depilatum are known and the species is included into the "List of Rare and Endangered Species of Fungi" ("Rejestr gatunków grzybów chronionych i zagrożonych" (GREJ), https://www.grzyby.pl/gatunki/ Boletus_depilatus.htm\#GREJ).

In Ukraine, until recently only one species of this genus was known, $H$. impolitum, a quite widespread mushroom commonly gathered in forests by local population. It has been recorded in Central Polissya, West, Right Bank and Left Bank Forest-Steppe, Left Bank Grass-Meadow and Grass Steppe, as well as Crimea (Zerova et al., 1979; Akulov, Prydiuk, 2007; Sarkina, 2018). The second species, H. depilatum, was found for the first time in Ukraine by I.S. Sarkina (2014a, b) in 2006 in Mys Martian Nature Reserve (South Coast of Crimea). The second and third finds of the fungus in 2008 were reported by the first author from Western Forest-Steppe (Heluta, 2012). After that, $H$. depilatum was recorded in the Mountain Crimea (Sarkina, 2014b) and the Carpathians (Berkela, Pokynchereda, 2015; Gleb, 2016). In 2016, a single fruit body collected in Central Polissya was brought by amateurs to the M.G. Kholodny Institute of Botany, NAS of Ukraine, for identification. Since recently, more observation data on the occurrence of this species have been provided through "Fungi of Ukraine", a social network group (https://www.facebook.com/groups/ Hryby.Ukrayiny/?ref=bookmarks). Consequently, distribution area of the fungus in the country was expanded to include the Right Bank Forest-Steppe, as well as several new localities were added to the earlier reported regions mentioned above.

Here we provide a description and illustrations of H. depilatum (Fig. 1), followed by a list of all currently known localities in Ukraine and a distribution map (Fig. 2).

Hemileccinum depilatum (Redeuilh) Šutara, Czech Mycol. 60(1): 55. 2008. - Bas.: Boletus depilatus Redeuilh, Bull. Soc. Mycol. France 101(4): 389. 1986 [1985]. - Syn.: Leccinum depilatum (Redeuilh) Šutara, Česká Mykol. 43(1): 4. 1989. - Xerocomus depilatus (Redeuilh) Manfr. Binder \& Besl, Micologia 2000 (Trento): 85. 2000.

Pileus 4-10(-15) cm wide, hemisphaerical, later convex, plano-convex to flattened cushion-shaped, 

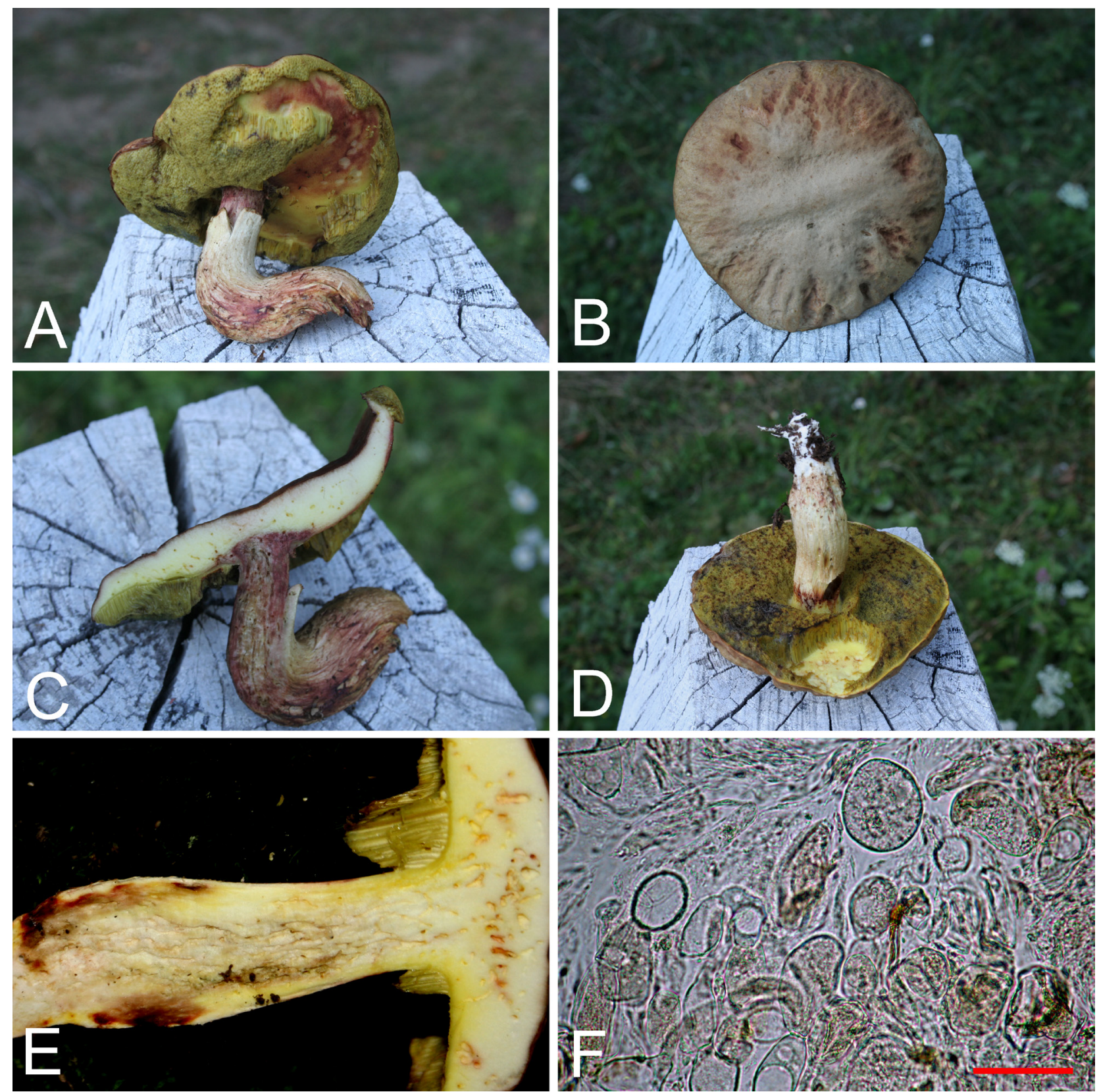

Fig. 1. Fruit bodies of Hemileccinum depilatum collected in Khmelnytsky Region (A-E); pileus pseudoepithelium composed of ellipsoid to subglobose cells (F). Bar: $50 \mu \mathrm{m}$ 


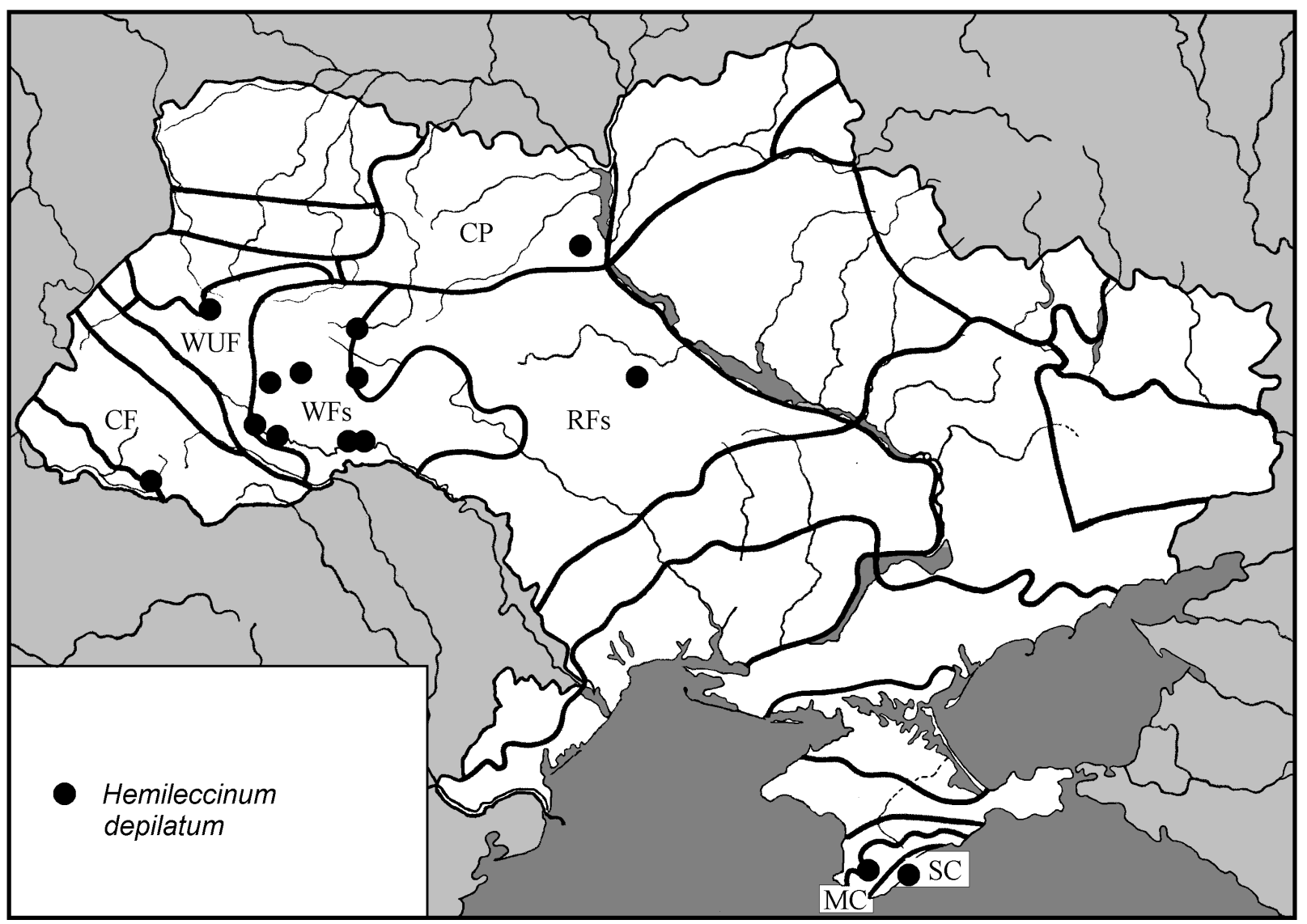

Fig. 2. Distribution of Hemileccinum depilatum in Ukraine (CF - Carpathian Forests, CP - Central Polissya, MC - Mountain Crimea, RFs - Right Bank Forest-Steppe, SC - Southern Crimea, WFs - Western Forest-Steppe, WUF - Western Ukrainian Forests)

surface uneven, slightly wrinkled or pitted, mostly glabrous, but at early stages finely tomentose in pits and at pileus margin, later completely glabrous, at first yellow-brown, then chestnut-brown, fading to ochre or tinged to flesh color (Fig. 1, A-D). Pileipellis nonseparable. In young fruit bodies pileipellis is composed of two layers, the upper soft trichoderm consisting of loosely intertwined filamentous hyphae and the lower layer formed by dense somewhat saddle-shaped hyphae. Soon after, as the upper layer starts to disappear, the lower one becomes a pseudoepithelium composed of ellipsoid to subglobose cells (Fig. 1, F). Hymenophore near stipe apex slightly depressed, sometimes almost free. Tubes up to (10-)15-20 mm long, deep yellow when young, olive-yellow with age. Pores minute, $0.5-1 \mathrm{~mm}$ in diameter, rounded, concolorous with the tubes, unchanging when bruised. Stipe 6-15 $\times$ $2.5-4(-4.5) \mathrm{cm}$, relatively fleshy, elongate clavate or elongate subfusoid, tapering, occasionally spindleshaped toward base, often distinctly curved, covered with scabrosities as in Leccinum, but less conspicuous, light-colored and not darkening, later partly collapsing; stipe surface light-yellow or whitish, in old fruit bodies sometimes with brownish to burgundy spots or reddish band. Stipe base covered with white or whitish, occasionally yellow-olive to brownish tangled basal tomentum. Partial veil and annulus absent. Context of stipe and pileus whitish, light-yellow, often more deep yellow above tubes and under stipe surface, at stipe base or all over the stipe in old fruit bodies sometimes with brown or brown-red spots (Fig. 1, E), or completely red-brown (Fig. 1, C), color unchanging when cut, odor unpleasant resembling iodoform, particularly in the lower part of the stipe, taste mild.

Macrochemical reactions. Pileus surface: $\mathrm{NH}_{4} \mathrm{OH}-$ violet. 
Spore print olive-brown. Spores $(10-) 12-14(-17) \times$ 4.5-6(-7) $\mu \mathrm{m}$, fusoid-ellipsoid, smooth.

Deciduous forests, predominantly under hornbeam, on alkaline soils. Solitary, very rare. July-August. Edible mushroom of low quality due to unpleasant odor.

Distribution in Ukraine. Autonomous Republic of Crimea, Bakhchisarai Region, Male Sadove village, 21.07.2013, N.O. Bagrikova (Sarkina, 2014b); Yalta City Council, Nikita Botanical Garden, Mys Martian Nature Reserve, 05.07.2006, I.S. Sarkina (Sarkina, 2014a, b). - Cherkasy Region, Lysianka District, Pochapyntsi village, 27.07.2017, V. Shulha. - Ivano-Frankivsk Region, Horodenka District, Daleshove village, 23.09. 2017, A. Yemchuk. - Kyiv Region, Borodyanka District, near Klavdievo-Tarasove settlement, 04.08.2016, collected by amateurs. - Khmelnytsky Region, Vinkivtsi town, 03.09.2019, N. Marysyk; Horodok district, Ivankivtsi village, 17.08.2019, V. Kydanchuk-Dronska; Kamianets-Podilskyi District, Kytaihorod village, 24.08.2008, V.P. Heluta; Lenivka village, 21.08.2008, V.P. Heluta, V.P. Hayova; Krasyliv District, Krasyliv town, 24.07, 20.08.2019, V. Kydanchuk-Dronska. Lviv Region, Zolochiv District, Yaktoriv village, 16.08.2019, O. Stepko. - Ternopil Region, Zalishchyky town, 28.09.2015, L. Burdeina-Domarad; Chortkiv town, 16.07, 19.08.2019, S. Flekey. - Transcarpathian Region, Rakhiv District, Carpathian Biosphere Reserve, Kisvyanske branch, 2015 (Berkela, Pokynchereda, 2015; Gleb, 2016).

Hemileccinum depilatum in its general appearance is quite similar to $H$. impolitum but differs in pitted, or hammered, pileus surface and microscopic structure of pileipellis. In $H$. impolitum, pileipellis hyphae are cylindrical and filamentous, with only a small number of terminal cells slightly broadened at the top. In $H$. depilatum, pileus surface undergoes conspicuous changes during its development. Initially, the pileipellis consists of two layers, the upper layer of loosely intervowen filamentous hyphae and the lower one with densely arranged hyphae. At this stage, the pileus surface appears finely tomentose. However, it becomes completely glabrous, as soon as the filamentous hyphae in the upper layer disappear. In the originally lower layer, gradually broadening hyphae become more or less inflated, so that the pileipellis eventually is composed of predominantly ellipsoid to subglobose cells. Thus the two species can be easily distinguished by this micromorphological character.
Hitherto, H. depilatum was recorded in Central Polissya, Western and Right Bank Forest-Steppe, Carpathian Forests, Mountain Crimea and Southern Crimea. According to administrative divisions in Ukraine, the species was reported from the Autonomous Republic of Crimea, Cherkasy, Ivano-Frankivsk, Kyiv, Khmelnytsky, Lviv, Ternopil and Transcarpathian regions. At present, in total 14 localities of the fungus are known in the country. However, the number of records increased due to additional data recently provided by amateur mycologists as a result of their field observations, rather than growing population trend of the fungus. Undoubtedly, $H$. depilatum is a rarely encountered species which is to be protected at the national level. It has been already recommended to include this species into the Red Data Book of Ukraine (Heluta, 2012). However, it is necessary to assess its conservation status nationally.

Nowadays, the red-listing system developed by the IUCN is widely internationally recognized (IUCN..., 2012). This system is based on assessing conservation status of all species against standard criteria applied to estimate extinction risk for the species and to assign it to one of the recommended categories (IUCN..., 2019). We have made a preliminary evaluation of the status of $H$. depilatum in Ukraine using the IUCN Red List categories and criteria, in accordance with special guidelines for fungal red-listing (Dahlberg, Mueller, 2011). This is a tentative assessment since the species was only recently recognized in the country (in 2006), therefore due to insufficient recording time for an ectomycorrhizal fungus, its population size cannot yet be estimated. However, based on the concept of functional individual (Dahlberg, Mueller, 2011) and current distribution of the fungus in the country, we can apply criterion D for its evaluation. The number of mature individuals in the known up to now 14 localities can be estimated as minimum 140, but maximum actual number of the localities can be increased in future, apparently not exceeding 100 . Thus, for the time being the species is assessed as Vulnerable (VU) under criterion D1.

At present, the main threat for $H$. depilatum is collecting its fruit bodies by local population. Therefore for conservation purposes it is important to protect already known sites, at least at the regional/local level, and to continue searching for new localities of the fungus in appropriate habitats. It is also essential to raise public awareness and to engage local people, primarily through social networks connecting professional mycologists with tens of thousands of amateurs. 


\section{Acknowledgements}

The authors are grateful to all amateurs (their names are listed in the article) who provided information on the localities of $H$. depilatum in Ukraine. The support offered by L.G. Lubinska and M.M. Riabyi during field research in Khmelnytskyi Region is much appreciated. This work was supported in part by the program "Support for development of the priority areas of scientific research" (CPCEL 6541230).

\section{REFERENCES}

Ainsworth A.M., Smith J.H., Boddy L., Dentinger B.T.M., Jordan M., Parfitt D., Rogers H.J., Skeates S.J. 2013. Red List of Fungi for Great Britain: Boletaceae. A pilot conservation assessment based on national database records, fruit body morphology and DNA barcoding. Peterborough: Joint Nature Conservation Committee (Species Status 14), $37 \mathrm{pp}$.

Akulov O.Yu., Prydiuk M.P. 2007. The preliminary checklist of boletoid fungi of Ukraine. Pagine di Micologia, 27: 117-144.

Assyov B., Denchev C.M. 2015. Boletus depilatus Redeuilh. In: Red data book of the Republic of Bulgaria. Vol. 1. Plants and fungi. Eds D. Peev, A.S. Petrova, M. Anchev, D. Temniskova, C.M. Denchev, A. Ganeva, Ch. Gussev, V. Vladimirov V. Sofia: IBER - BAS \& MOEW, p. 776.

Bakker H.C., Noordeloos M.E. 2005. A revision of European species of Leccinum Gray and notes on extralimital species. Persoonia, 18: 511-587.

Berkela Yu.Yu., Pokynchereda V.F. 2015. Zvit pro vykonannya planu zakhodiv z naukovoyi ta naukovo-tekhnichnoyi diyalnosti Karpatskoho biosfernoho zapovidnyka za 2015 r. [Звіт про виконання плану заходів з наукової та науково-технічної діяльності Карпатського біосферного заповідника за 2015 p.] http://cbr.nature. org.ua/doc/CBR_Zvit-nauka-2015.pdf

Bertault R. 1980. Amanites du Maroc. (Troisième contribution). Bulletin de la Société mycologique de France, 96(3): 271-287.

Binder M., Besl H. 2000. 28S rDNA sequence data and chemo-taxonomical analyses on the generic concept of Leccinum (Boletales). Micologia (Trento): 75-86.

Dahlberg A., Mueller G.M. 2011. Applying IUCN redlisting criteria for assessing and reporting on the conservation status of fungal species. Fungal Ecology, 4(2): 147-162. https://doi.org/10.1016/j.funeco.2010.11.001

Doğan H.H., Aktaş S., Öztürk C., Kaşik G. 2012. Macrofungi distribution of Cocakdere valley (Arslanköy, Mersin). Turkish Journal of Botany, 36: 83-94. https:// doi.org/10.3906/bot-1010-9

Gleb R.Yu. 2016. In: Rehionalni aspekty florystychnykh $i$ faunistychnykh doslidzhen. Materialy Tretoi mizhnarodnoi naukovo-praktychnoi konferentsii (13-14 travnya 2016 r., smt Putyla). Chernivtsi: Druk Art, pp. 313-315. [Глеб Р.Ю. 2016. Рідкісні види грибів Карпатського біосферного заповідника. У зб.: Регіональні аспекти флористичних і фауністичних досліджень. Матеріали Третьої міжнародної науково-практичної конференції (13-14 травня 2016 р., смт Путила). Чернівці: Друк Арт, с. 313-315].

Gyosheva M.M., Denchev C.M., Dimitrova E.G., Assyov B., Petrova R.D., Stoichev G.T. 2006. Red List of fungi in Bulgaria. Mycologia Balcanica, 3: 81-87.

IUCN. 2012. IUCN Red List Categories and Criteria: Version 3.1. Second edition. Gland, Switzerland and Cambridge, UK: IUCN. Available at: https://www.iucnredlist.org/ resources/categories-and-criteria

IUCN Standards and Petitions Committee. 2019. Guidelines for Using the IUCN Red List Categories and Criteria. Version 14. Prepared by the Standards and Petitions Committee. Available at: http://www.iucnredlist.org/ documents/RedListGuidelines.pdf

Halling R.E., Fechner N., Nuhn M., Osmundson T., Soytong K., Arora D., Binder M., Hibbett D. 2015. Evolutionary relationships of Heimioporus and Boletellus (Boletales), with an emphasis on Australian taxa including new species and new combinations in Aureoboletus, Hemileccinum and Xerocomus. Australian Systematic Botany, 28: 1-22. http://dx.doi.org/10.1071/SB14049

Heluta V.P. 2012. In: Roslynnyi svit u Chervoniy knyzi Ukrayiny: vprovadzhennya Hlobalnoyi stratehiyi zberezhennya roslyn. Materialy II Mizhnarodnoyi naukovoyi konferentsiyi. Kyiv: Palyvoda A.V., pp. 201-204. [Гелюта В.П. 2012. Огляд представників роду Boletus L. як претендентів на включення до "Червоної книги України". Рослинний світ у Червоній книзі України: впровадження Глобальної стратегії збереження рослин. Матеріали II Міжнародної наукової конференції (9-12 жовтня 2012 р., м. Умань, Черкаська обл.). Київ: Паливода А.В., с. 201-204].

Holec J., Beran M. 2006. Červeny seznam hub (makromycetů) Česke republiky. Praha: Přiroda, $282 \mathrm{pp}$.

Mustafabayli E.H., Aghayeva D.N. 2019. New mushroom records for the mycobiota of Azerbaijan. Ukrainian Botanical Journal, 76(4): 356-361. https://doi. org/10.15407/ukrbotj76.04.356

Sarkina I.S. 2014a. Sbornik nauchnykh trudov GNBS, 139: 73-78. [Саркина И.С. 2014а. Новые виды микобиоты заповедника "Мыс Мартьян": макромицеты. Сборник научных трудов ГНБС, 139: 73-78].

Sarkina I.S. 2014b. In: Roslynnyi svit u Chervoniy knyzi Ukrayiny: vprovadzhennya Hlobalnoyi stratehiyi zbere-zhennya roslyn. Materialy III Mizhnarodnoyi konferentsiyi. Lviv, pp. 187-189. [Саркіна I.C. 2014b. Доповнення до розповсюдження деяких включених до Червоної книги України грибів на Кримському півострові. У зб.: Рослинний світ у Червоній книзі України: впровадження Глобальної стратегіїзбережкення рослин. Матеріали III Міжннародної конференщії (4-7 червня 2014 р., м. Львів). Львів, с. 187-189].

Sarkina I.S. 2018. Gribyznakomyeineznakomye. Spravochnikopredelitel gribov Kryma. Simferopol: Biznes-Inform, 488 рр. [Саркина И.С. Грибы знакомые и незнакомые. Справочник-определитель грибов Крыма. Симферополь: Бизнес-Информ, 488 с.]. 
Šutara J. 2008. Xerocomus s. 1. in the light of the present state of knowledge. Czech Mycology, 60(1): 29-62.

Šutara J., Mikšík M., Janda V. 2009. Hřibovité houby. Čeled' Boletaceae a rody Gyrodon, Gyroporus, Boletinus a Suillus. Praha: Academia, 296 pp.

Wu G., Feng B., Xu J., Zhu X.-T., Li Y.-C., Zeng N.K., Hosen I., Yang, Z.L. 2014. Molecular phylogenetic analyses redefine seven major clades and reveal 22 new generic clades in the fungal family Boletaceae. Fungal Diversity, 69(1): 93-115.
Wu G., Li Y.-Ch., Zhu X.-T., Zhao K., Han L.-H., Cui Y.-Y., Li F., Xu J.-P., Yang Zh.L. 2016. One hundred noteworthy boletes from China. Fungal Diversity, 81(1): 25-188. https://doi.org/10.1007/s13225-016-0375-8

Zerova M.Ya., Sosin P.Ye., Rozhenko H.L. 1979. Vyznachnyk hrybiv Ukrayiny. Vol. 5. Bazydiomitsety. Book 2. Boletalni, strobilomitsetalni, trykholomatalni, entolomatalni, rusulalni, aharykalni, hasteromitsety. Kyiv: Naukova Dumka, 566 pp. [Зерова М.Я., Сосін П.Є., Роженко Г.Л. 1979. Визначник грибів Украӥни. Т. 5. Базидіоміцети. Книга 2. Болетальні, стробіломіцетальні, трихоломатальні, ентоломатальні, русулальні, агарикальні, гастероміцети. Київ: Наукова думка, 566 с.].

Recommended for publication by M.M. Sukhomlyn 